This item was submitted to Loughborough's Research Repository by the author.

Items in Figshare are protected by copyright, with all rights reserved, unless otherwise indicated.

\title{
Still life in the old attack dogs: the press
}

PLEASE CITE THE PUBLISHED VERSION

http://dx.doi.org/10.1057/9781137366115

\section{PUBLISHER}

Palgrave Macmillan (individual chapters @ respective authors)

\section{VERSION}

AM (Accepted Manuscript)

\section{PUBLISHER STATEMENT}

This work is made available according to the conditions of the Creative Commons Attribution-NonCommercialNoDerivatives 4.0 International (CC BY-NC-ND 4.0) licence. Full details of this licence are available at: https://creativecommons.org/licenses/by-nc-nd/4.0/

\section{LICENCE}

CC BY-NC-ND 4.0

\section{REPOSITORY RECORD}

Deacon, David, and Dominic Wring. 2019. "Still Life in the Old Attack Dogs: The Press". figshare. https://hdl.handle.net/2134/21439. 


\section{Still Life in the Old Attack Dogs: The Press}

\section{David Deacon and Dominic Wring}

\section{Introduction}

During the 2015 campaign there was considerable negativity and partiality in much press reporting; it was not difficult to find examples of where robust political partisanship descended into personal vilification. Some of this was the kind of journalism that had been repeatedly highlighted and criticized only a few years before, most notably in the House of Commons following the 2011 hacking scandal and subsequently during the ensuing year-long Leveson Inquiry. As a counter balance, some opinion-forming commentators believed this election might witness digital platforms assuming a more significant, potentially influential role in framing public participation in, and perceptions of, the contest. At the close of the campaign Alastair Campbell observed: 'Why has social media been so important? Politicians aren't trusted any more, business isn't trusted like it was, the media is certainly not trusted like it was... The genius of social media, and the genius of Facebook is the concept of the friend. We trust our friends'.

Those who believed social media were potentially transformative during the election suggested the new online forums would host rather than lead opinion, enabling citizens to take a more active role in the campaign - drawing up their own informational diet, mobilising the like-minded, sharing insights and evidence, challenging journalistic falsehoods, subverting party imagery through memes, and so on. For their part the main parties invested considerable efforts in trying to accommodate the 'wonderful world' of Web 2.0. The most celebrated example of this came in the last week of the campaign when Ed Miliband was interviewed by the celebrity and activist, Russell Brand, on his youtube channel, the Trews. Amongst many things, the unexpected outright victory of the Conservatives provided a realitycheck upon some of the more outlandish claims made of the democratising potential of social media. Similarly 'Milifandom' - a twitter-led, ebullition of ardour for the Labour leader led by teenage admirers- didn't make it past the ballot box. Although there are dangers in writing off the significance of social media too readily (and in the 
process overemphasising its distinctiveness from traditional news journalism), Steven Barnett believes digital platforms generally provided more of an 'echo chamber' than a megaphone.i These forums appear to have been a means for communing with the like-minded rather than converting the unconvinced. By contrast there is substantial circumstantial evidence that the influence of 'legacy' media lives on, not least in the national printed press, discussion of which forms the basis of this chapter.

\section{The press: still a critical mass medium}

There is no question that the UK press has experienced challenging market conditions in the five years since the last General Election. Tables $\mathbf{1}$ and $\mathbf{2}$ compare circulation and readership figures for print copies of national daily and Sunday newspapers in 2010 and 2015. There was a 30.6\% decline in daily circulation and a $35.6 \%$ drop in Sunday newspaper circulation in this period alone. Readership has also reduced substantially, down $33.6 \%$ for the dailies and $36.4 \%$ for the Sunday editions. The reduction in readership has been mitigated by the growth of on-line readership of several titles (see Table 1 ), but the continuing struggle to find a viable digital business model has meant this has done little to alleviate the financial pressures facing the industry. News UK's introduction of paywalls for both its dailies' (Sun and The Times) digital content may have generated additional revenue but, as the figures show, it has reduced their online presence.

Despite the challenge facing the traditional print media industry, the figures in Tables $\mathbf{1}$ and $\mathbf{2}$ also show that the UK national press still has considerable reach. Daily readership of hard copy newspapers (excluding The Financial Times) averaged 16.7 million in April 2015, and this figure increases to 22.3 million when on-line readerships are included. Furthermore the National Readership Survey data reveal that press readership is strongly biased towards older people with $80 \%$ of readers being over 35 years of age. This demographic group also constitutes the section of the electorate most likely to vote and thereby underlines the enduring significance of printed newspapers. Given many of these readers still largely engage with the medium in its hard copy format this non-interactive version is by design obviously less 'social' in construction. For David Thorburn the way this news is consumed is 
important because these titles 'organize the world each day in a coherent way, and even to choose not to read a particular article is to make contact with and become aware of another angle or perspective on the world'. iii It is this structured management of news and views that makes these newspapers' interventions potentially so compelling for the still significant numbers of loyal readers.

Throughout the final weeks of the 2015 campaign, most available evidence suggested the result was on a knife-edge, with the electorate divided over the merits of the main contenders. The perception that this would be a close run election did little to encourage even-handedness in many quarters; indeed, it appears to have stimulated partiality within sections of the print media. This inevitably drew attention to cui bono questions: whose interests were being served by such propagandising and what were their motives? Concerns about the influence of newspaper proprietors surfaced during the campaign when The Independent published a story about News UK owner Rupert Murdoch two weeks before polling day. ${ }^{\text {iv }}$ This report suggested that Murdoch had visited London in February to personally instruct staff on his Sun newspaper to get their 'act together' and help prevent Ed Miliband becoming Prime Minister. It was widely speculated that the veteran proprietor was seeking revenge on a Labour leader who had been vocal in his criticism of News International (as News UK was previously known) during the 2011 hacking scandal. The episode had also embarrassed David Cameron when it was revealed that his former spin doctor Andy Coulson was implicated because of his prior editorship of the News of the World, the paper responsible for widespread criminality. Cameron felt pressured to launch the Leveson Inquiry but ultimately distanced himself from the subsequent Report's recommendations despite having pledged to support them unless they were 'bonkers'. " A Miliband-led government's preparedness to revisit the issue presented an obvious threat to Murdoch's interests.

The Sun's official response to The Independent's story about Murdoch's alleged interference was to state that their editorial line 'is informed by how the political parties approach the issues that matter most to our readers'. vi But the credibility of this claim was strained further in the last days of the election, when it emerged that a PR Agency working for the newspaper had offered paid incentives for 'case studies' for coverage in the guise of '(ideally Sun readers) who are going to vote Conservative and have a good news story to tell'. vii Close relations between 
newspapers and political parties of this kind are, of course, nothing new. ${ }^{\text {viii }}$ But there were several instances that exposed the scale of this co-operation, even connivance, in 2015 such as the Sun offering appearance money to contributors willing to endorse the Conservatives. Richard Desmond, owner of the Express and Star newspapers, was more upfront in making his support for UKIP public when he donated £1million to the party during the campaign. It therefore came as no surprise when the Express newspapers formally declared their backing for Nigel Farage. The Mirror newspapers too continued their longer established association with Labour and, as will be shown, articulated key themes from the party's campaign in their coverage of the election. Perhaps reflecting this David Cameron, guided by media advisors including Craig Oliver, rejected an invitation to be interviewed by the Sunday People and was duly 'empty chaired' by the title (5 April). Non co-operation between parties and certain newspapers was a feature of the election. For instance the Labour press operation, led by spin doctors such as Tom Baldwin, were accused of instituting a 'ban' on press critics attending the party's campaign launch ('Mili bans Sun from his bash', Sun, 28 March).

Allegations of proprietorial influence were not restricted to the 'popular' press and involved so-called 'quality' newspapers. The most notable came early on in the campaign when the Daily Telegraph influenced the news agenda through devoting its front-page to an 'open letter' from 103 senior corporate executives hailing the successes of the Conservatives' economic policies and criticising opposition plans ('100 business chiefs: Labour threatens Britain's recovery', 1 April). The story lead most broadcast news bulletins that day. But questions subsequently emerged about its provenance and independence, with several signatories revealed to be Tory donors and others insisting that their name be removed as they had been misled as to the letter's tone and purpose. After initial denials there was an admission from Central Office that its officials had offered a 'guiding hand' in organising the intervention. ${ }^{\text {ix }}$ This was only one incident. As this chapter will demonstrate the Conservatives in particular were able to harness and use the bulk of the print media for their own campaigning purposes. Initial consideration will be given over to how the different newspapers covered the election as partisan titles rather than merely media organisations. Separate discussions will focus on the popular and quality press. Further to this there is an analysis of the key themes and policies reported by 
the press and how they helped to frame debate over the perceptions of the rival leaders, the economy and a range of other issues. Consideration will also be given to how readers voted according to their choice of newspaper as well as the equivalent figures for 2010.

\section{Polarised and polemical: 'popular' partisanship}

During their 1970s and 1980s heyday the term 'tabloid' became synonymous with a polemical, irreverent kind of journalism and politics was particularly subjected to this treatment. More recently the adoption of the tabloid format, though not the associated style, by former broadsheets such as the The Times and Independent has meant their more populist rivals have been redefined as the 'populars'. The latter remain deeply political animals and still appear keen to cultivate and persuade their audiences, particularly during elections. So for example when the best-selling Sun formally announced its long anticipated endorsement of the Conservatives it did so by making a jokey allusion to another major story, the then imminent birth of Princess Charlotte, by depicting Cameron as a new-born emblazoned with headline 'IT'S A TORY!' (30 April). The editorial praised the party's economic policy and decision to hold an EU referendum while warning of the threat posed by the 'saboteurs' of the Scottish National Party. In sharp contrast the Scottish Sun endorsed Nicola Sturgeon on a front-page that depicted her as Star Wars hero Princess Leia ('STUR WARS- A NEW HOPE, MAY THE $7^{\text {TH }}$ BE WITH YOU: WHY IT'S TIME TO VOTE SNP', 30 April). Ironically the English edition of the paper had earlier superimposed Sturgeon's face on a photo of singer Miley Cyrus atop a wrecking ball (a scene from the latter's music video) to warn that the SNP would demolish the British economy if it gained any leverage over a Labour led coalition government ('TARTAN BARMY', The Sun, 10 March).

The various ominous forces the Sun suggested would dominate Prime Minister Miliband were a recurrent theme of its election coverage and were collectively illustrated as a mythical hydra monster: 'The six Edded beast' (29 April). Sturgeon's was one among the creature's half dozen demonic heads along with Miliband himself, deputy Harriet Harman, union leader Len McCluskey, celebrity activist Russell Brand and Sinn Fein President Gerry Adams. Adams' inclusion referenced a previous 
claim that normally absentionist Irish republican MPs might take up their Westminster seats for the first time after the election to help Labour form the government ('DESPERATE LABOUR WOOING SINN FEIN', The Sun, 28 January). Although the party vehemently denied the story the Conservatives issued an advert emblazoned with the aforementioned headline that depicted Alex Salmond with his arm around Miliband alongside a smiling Adams.

The Sun recognised the threat to the Conservatives posed by UKIP's advance and was quick to highlight any perceived downturn in its polling fortunes ('Ukip's slump', 7 April). Similarly 'UKIP... U LOSE' informed readers about 'the 26 marginals where voting for Farage's party would allow Labour to steal a win on Thursday' (The Sun, 5 May). The same feature also listed the fourteen seats where it claimed supporting the Liberal Democrats could help 'get Cam in No10'. The paper reinforced its warning about the consequences of supporting UKIP in a front-page story featuring 'White Van Dan'. The man in question, Dan Ware, was the owner of the house decorated with St George flags that MP Emily Thornberry had publicised on twitter during the 2014 Rochester by-election. Thornberry was duly sacked from Labour's frontbench having been accused of snobbery by The Sun who duly interviewed $\mathrm{Mr}$ Ware. The paper returned to 'Dan' during the campaign as a representative of 'hardworking families' and subsequently confirmed he would be voting Conservative, disliked the 'racist' UKIP and also supported staying in the European Union ('VAN OF THE PEOPLE', The Sun, 28 April). In sharp contrast the paper portrayed Mike Holpin, 'BRITAIN'S MOST SHAMELESS DAD. 40 KIDS BY 20 WOMEN', as the ultimate example of what the same day's editorial denounced as Labour's 'bloated benefits culture' (1 April).

The single most memorable Sun intervention during the campaign came in its eve of poll edition. The front-page was given over to the by then widely publicised and very unflattering photograph of Ed Miliband eating breakfast on an early morning visit to Covent Garden during the 2014 European election. ${ }^{\mathrm{X}}$ The Sun reproduced this image with the headline: 'SAVE OUR BACON: Don't swallow his porkies and keep him OUT'. The front-page editorial continued: 'This is the pig's ear Ed made of a helpless sarnie. In 48 hours he could be doing the same to Britain' (6 May). The attention-grabbing imagery provoked a reaction but not all of it was favourable, with 
one Guardian contributor questioning whether the supposedly jokey piece contained a more sinister, anti-Semitic message given the Labour leader's Jewish heritage. ${ }^{\text {xi }}$

The Daily Mail vied with The Sun to be the most polemical newspaper during the election. The paper's highly combative approach was demonstrated in a series of attacks on rival politicians including the outgoing Deputy Prime Minister who had clashed with Cameron in their face-to-face televised debate ('Treacherous Clegg knifes Dave', 3 April). Following her perceived success in the same encounter SNP leader Nicola Sturgeon was labelled the 'MOST DANGEROUS WOMAN IN BRITAIN' (Daily Mail, 4 April). Similarly even a seemingly innocuous photograph of a smiling First Minister was framed negatively: 'Sturgeon gloats as SNP is set to win EVERY seat in Scotland' (30 April). But this was mild, however, compared to Mail columnist Dominic Lawson's attack on 'THE SCOTTISH NASTY PARTY' in which he denounced their 'intimidation and (an) intolerance of dissent (that) reeks of fascism' (Daily Mail, 20 April). The alleged threat posed by a powerful SNP was contrasted with the perceived weakness of Ed Miliband who the Mail feared would be dominated by the Nationalists in a coalition government ('Swaggering Salmond boasts: I'll be writing Labour's budget', Daily Mail, 23 April). Miliband's vulnerability to pressure from Unite leader Len McCluskey also formed the basis of stories about his union's sponsorship of several parliamentary candidates ('UNION'S SINISTER HOLD OVER MILIBAND', Daily Mail, 22 April; 'RED LEN: I OWN LABOUR', 24 April). This ridicule culminated with a front-page photograph of the prospective Prime Minister's meeting with activist Russell Brand accompanied by the headline: 'Do you really want this clown ruling us? (And, no, we don't mean the one on the left)' (Daily Mail, 29 April). Pointedly the editorial formally endorsing the Conservatives denounced Miliband as 'a class war zealot' and revived an earlier Mail attack on him for being 'schooled by his Marxist father' ('For sanity's sake, don't let a class war zealot and the SNP destroy our economy- and our very nation', 6 May). ${ }^{\text {ii }}$

The Mail was more cautious in dealing with the threat to the Conservatives from Nigel Farage's party because as the normally forthright columnist Stephen Glover observed: 'There's hardly a word I disagree with in Ukip's manifesto. And I know the other parties are lying to me. But...' (Daily Mail, 16 April). The paper's 'midmarket' rival the Daily Express showed less reluctance in embracing the Eurosceptic party's cause. The title had long been prominent in its clear, unequivocal call for 
Britain to the leave the European Union. Links between the paper and UKIP had been forged over some time by former columnist turned MEP Patrick O'Flynn and proprietor Richard Desmond who became a prominent donor. Consequently during the campaign the Express provided Farage and his colleagues with sympathetic coverage and this culminated with a formal endorsement on polling day itself: "Vote Ukip and help Britain to break free from the EU' (7 May). The Sunday Express took a similar line, arguing the party 'is in touch with ordinary people' (3 May). But it should be noted that Express columnists also provided anti-Labour commentaries that were as potentially useful to the Tories as UKIP. ${ }^{\text {xiii }}$

Richard Desmond's 'red-top' newspaper, the Daily Star, has not formally endorsed a party in the last two General Elections. ${ }^{\text {xiv }}$ This stance logically follows the title's decision not to publish dedicated editorial commentaries on any issue, political or otherwise. During the campaign the Star adopted a mocking tone, noting the number of 'ruddy days to go' each time it presented its limited electoral coverage. Nonetheless the newspaper did highlight the link between Desmond and Nigel Farage in a report that featured a photograph of them announcing the proprietor's $£ 1$ million donation to UKIP. The businessman was quoted as liking the party's commitment to the 'common man' and hostility towards the 'elitists' running its electoral rivals (Star, 17 April). And although the Star did not emulate Desmond's other newspaper, the Express, and formally support UKIP it did offer the party some sympathetic coverage. On St George's Day, for instance, the paper featured a smiling Farage posing with the national flag and beer in front of a pub to 'drink a toast to England's patron saint' ('FLY FLAG FOR ENGLAND', Daily Star, 23 April). The eve of poll edition also featured an advert of the UKIP leader with his now customary pint accompanied by the slogan 'Thirsty for Change?' and a signed letter urging readers to 'BELIEVE in BRITAIN' and vote for his party the following day (6 May).

Alone among the popular daily newspapers the Daily Mirror and its various sister titles took a very different line on Europe as well as party politics more generally. Recycling phraseology that had originally accompanied the notorious anti-Labour Sun election day 1992 front-page the paper warned the Conservatives' planned EU referendum would trigger an exodus of businesses: 'If Cam wins will the last big firm to leave Britain please turn out the lights' (Daily Mirror, 25 April). The newspaper 
routinely featured attacks on David Cameron and George Osborne that concluded with a front-page polling day exhortation to vote Labour in order to 'SEND EM' PACKING' courtesy of a 'MIRROR REMOVALS' van (7 May). Inside the editorial declared 'Let's make today the dawn of a better day'. North of the border, the Mirror's sibling, the Daily Record, counted down the number of days 'TO BOOT OUT THE TORIES'. The Sunday People also railed against the Conservatives. In an emotive endorsement of Labour, the paper's editorial cited a primary motivation was to see an end to the 'hateful Bedroom Tax' it claimed had caused suicides ('VOTE IN MEMORY OF THEM', 3 May). The Mirror papers also attacked other parties. Recognising their potential threat to Labour, veteran columnist Paul Routledge denounced UKIP as 'Nasty Nigel and the Little Englanders' (Daily Mirror, 29 April). The Sunday Mirror turned its attention to another rival in: '50 shades of green... inside the weird world of party leader Natalie Bennett' and accused her partner Jim Jepps of having controversial attitudes towards sex offenders (19 April). The Mirror also published more positive and supportive material such as the front-page devoted to Ed Miliband in which he declared 'My Pledge' to help voters and their families because '(Y)ou can trust me' (13 April).

\section{Qualified judgements: the 'qualities' decide}

While the so-called 'popular' daily and Sunday newspapers were mostly keen to promote their partisan preferences during the campaign what were once known as 'broadsheets' were, for the most part, more circumspect. And whereas the former allied themselves to a particular party, three of the five so-called 'qualities' endorsed the formation of another Conservative-Liberal Democrat coalition government. For its part The Financial Times argued '(T)he compelling case for continuity' (1 May). The editorial credited several Conservative-led initiatives but also made clear its support for continuing UK membership of the European Union, a stance most associated with the Liberal Democrats. Earlier on in the campaign The Independent picked up on this issue through giving prominence to Nick Clegg's denunciation of the 'swivel-eyed' right-wing Conservative and UKIP MPs he feared would hold Cameron 'to ransom' over Britain's continuing role within the EU (10 April). The paper eventually declared for what it pointedly called a 'Lib-Con' government in an 
endorsement, '(I)n defence of liberal democracy', that applauded Clegg's party while calling for the Coalition's re-election '(F)or all its faults' (The Independent, 5 May).

The Liberal Democrat leader was singled out in a Times editorial 'Vote Clegg' which urged Conservative voters in his constituency to lend him their support on polling day (5 May). The newspaper's formal declaration, 'Britain's Vital Choice', the following day called for the re-election of the Coalition because it had taken 'tough decisions' on the economy (The Times, 6 May). It did, however, lament over how 'the Conservatives have strayed rashly from the fiscal probity that is supposed to be their hallmark'. Although decidedly Eurosceptic in tone, the editorial acknowledged polls indicating Liberal Democrat support would be needed to ensure continuation of what it believed had been a successful government. The statement warned against the 'tyranny' posed by the SNP, a prospective partner in an alternative centre-left coalition. The Nationalists also featured in the Sunday Times' endorsement '(A) conservative case for the Conservatives', 3 May). Reflecting on a 'dull campaign' in which 'politicians have droned us into bored submission', the editorial presented the case for a Cameron led government. Although the statement acknowledged the merits of supporting Clegg and his 'closest Lib Dem' ministerial colleagues it concentrated on comparing the Conservative economic plans with Labour's 'populist "soak the rich" policies' that it contended would 'deter inward investment'.

The Daily Telegraph was the quality newspaper that provided by far the most strident endorsement of a party, even writing to subscribers imploring them to vote Conservative. $^{\mathrm{xv}}$ Its declaration of there being '(A) clear choice for Britain' was followed by an attack on 'a Labour campaign strewn with gimmicks, half-truths and downright lies' (7 May). It conjured up a vision of future 'economic and social wreckage' with the party having 'lurched to the Left' under a leader who espoused 'an insidious anti-wealth, soak-the-rich ethos'. Although it acknowledged the Tories had 'made mistakes' in office, the Sunday Telegraph also made clear its position, declaring 'Vote Conservative for the good of the country' (3 May). Predictably the left-leaning Guardian came to a very different conclusion. Having abandoned Labour for the Liberal Democrats in 2010, the paper reversed the decision having acknowledged the 'visceral' antipathy of rival newspapers towards Ed Miliband. The paper believed these 'personal' attacks were in part motivated by the politician's reformist media policy (The Guardian, 1 April). During the closing stages of the 
campaign a leader comment concluded: 'Britain confronts a profound choice. Labour offers the best chance of a new direction' and urged readers to think of those less fortunate than themselves when voting (The Guardian, 2 May). The Observer agreed with its daily sister paper. Writing that the country was at a 'crossroads', it suggested a new direction was necessary and that '(O)nly Labour offers that vision' (3 May).

\section{The 'horserace' campaign: covering the electoral 'process'}

Process is a term describing much of the so-called 'horse race' style of reporting that features quite prominently in modern election campaigns (Table 3). Topics of particular relevance were the leaders' public and private lives together with aspects of their campaign strategies and whether or not these appeared to be successfully engaging the electorate. Electoral process also refers to the coverage devoted to the likelihood of there being another hung parliament and coalition government. This widely anticipated outcome to the election encouraged a significant amount of news reporting to make routine and copious references to the various polling findings published throughout the campaign. Many of these surveys were commissioned by rival newspapers and cumulatively helped create a narrative that the race was too close to call. Dedicated analysis was provided by polling experts YouGov President Peter Kellner for The Times, Alberto Nardelli of The Guardian and Professor John Curtice writing in The Independent.

When citing polling in campaign reports newspapers tended to give particular prominence to those surveys supporting their favoured election outcome. So, for example, the Daily Mirror keenly reported an apparent 'surge' of support of $4 \%$ for Labour during the campaign ('ED'S UP AGAIN', 10 April). Conversely a Tory leaning newspaper appeared to revel in publishing a 'leaked' survey report on the Thanet South constituency indicating the UKIP leader was unlikely to become its MP ('FARAGE BURIES "LOSER" POLL', Mail on Sunday 5 April). Polling was noticeably integral to newspaper analysis of the televised debate between the seven leaders. Survey figures were selectively used to frame perceptions of the rival candidates' performances. In a report entitled 'OOPS! I JUST LOST MY ELECTION' the Sun suggested Miliband had failed as the 'PM COMES OUT FIGHTING' (3 April). 
The 'quality' press were not averse to making selective interpretations, albeit with characteristically greater subtlety. Whereas a front-page Guardian report suggested 'Labour buoyed as Miliband edges Cameron in snap poll', the same day's Telegraph declared 'Miliband flops as outsiders shine' (3 April). It was also notable what these and other headlines did not say about whom had 'won' the debate following the publication of YouGov poll that had placed Sturgeon and Farage ahead of the main two contenders for the premiership (The Sun, 3 April).

The perceived closeness of the election race as reported in successive newspaper polls created a widespread expectation of another hung parliament. Successive reports reinforced this view with Peter Kellner confidently predicting '(T)here will be a second election before the end of 2015' (The Times 22 April). Similarly fellow Times contributor Sam Coates forecast '(T)he next government will teeter on the edge every night. Political journalists will be taking camp beds to work' (16 April). Some questioned the prevailing consensus and the polling on which it was based. Reflecting on a 1992 Conservative victory that had not been anticipated by the preceding polls, John Rentoul suggested 'Cameron's best hope is the return of the "shy Tories"' (Independent on Sunday 12 April). Rachel Sylvester also cautioned that Likud's surprising triumph in the recent Israeli election was an example of how voter surveys do not necessarily accurately predict outcomes ('Labour and Tories turn up the fear factor', The Times 28 April).

David Cameron was in his tenth year as party leader and fifth as Prime Minister so was already reasonably well known to a voting public who, by the time of the General Election, were likely to have formed an opinion of him. For media detractors such as Kevin Maguire 'cynical' Cameron was 'the posh boy who vowed to mend what he called a Broken Britain' (Daily Mirror 30 March). The Prime Minister appeared keen to counter such criticisms through favourable press coverage. On one occasion, when he was supposedly having a 'day off' campaigning, Cameron was photographed bottle-feeding a small farm animal and the image widely disseminated by various newspapers (“'Lamb Cam!" PM with lamb', Daily Mail 6 April). An informal looking Cameron was also interviewed alongside colleague, friend and potential successor George Osborne ('The Blue Brothers', The Sun 1 April). Following on from her high profile role in the last campaign Samantha Cameron made prominent appearances in newspapers most sympathetic to the 
Conservatives. The Sun published a two page spread in which the Prime Minister's wife talked about their late son ('SAM CAM.I.AM', 6 April). The impact of caring for their disabled child informed the headlines of her interviews with both the Mail and Telegraph in which family photographs of the couple's children were used to illustrate the features ('Dave and Sam: Our crisis over Ivan', Daily Mail, 6 April; 'The strain of caring for Ivan took Dave and me to the limit', Telegraph, 6 April).

It was noteworthy how much less 'Cleggmania', human interest coverage the Liberal Democrat leader and his family received compared with the last election. The Independent featured one of the few interviews with the Deputy Prime Minister's wife, albeit an encounter that focused more on her work as a food writer than political spouse (22 April). Understandably there was greater scrutiny of the Labour leader and his family. In response to this, and possibly Mrs Cameron's intervention, Justine Miliband featured in her own sympathetic interview with the Daily Mirror in which she talked about her family life and how she had got to know her husband: 'Ed bandaged me up after I was bitten by a Doberman and I fell in love' (9 April). The seeming conventionality of Ed Miliband was, however, challenged the following day. In 'Red Ed's very tangled love life' Daily Mail columnist Andrew Pierce suggested Miliband had been romantically involved with four members of an 'incestuous, privileged clique' comprising well connected women in journalism and politics (10 April). Rather than harming the Labour leader, the article in some ways flattered him. But even sympathetic print journalists acknowledged Miliband had an image problem and still some way to go before overcoming it. So when he replied 'hell, yes!' in response to Jeremy Paxman's question as to whether he was 'tough enough' to be Prime Minister, Kevin Maguire compared his reaction to that of comedic character and personification of naff Alan Partridge (Daily Mirror 30 March). Later in the campaign John Rentoul speculated as to whether Miliband might have peaked too soon having managed to change the 'narrative' about him in his favour (Independent on Sunday 26 April).

The Labour leader's vulnerability was symbolically highlighted when he stumbled on stage during the BBC Question Time Leaders' Special, the last major televised broadcast of the campaign. But it was his deployment of the so-called 'EdStone', a huge tablet carved with six key pledges, in the final week of the campaign that attracted most disdain. Labour sympathising Times columnist Philip Collins 
dismissed the photo-opportunity as the 'most risible political stunt' (5 May). The Telegraph likened the incident to the "'Kinnock" gaffe moment', a poignant reference to the rally shortly before his 1992 defeat in which Miliband's mentor had appeared to prematurely celebrate, and thereby undermine, his party's chances of victory (4 May). Other critics ridiculed the Labour leader for agreeing to be interviewed by celebrity activist Russell Brand for his online news service The Trews. The Daily Star, like David Cameron, dismissed the encounter as a joke while The Times suggested 'Ed's attempt at Brand awareness backfires' ('Red Ed \& Brand talk total ballots', Daily Star, 29 April; The Times 29 April). Brand was also heavily criticised, with one former partner calling him 'a mysogynist' (Mail on Sunday 3 May). Predictably it was the Guardian which took the opposing view, suggesting Miliband's attempt to cultivate younger voters was a 'tactical gamble' that columnist Owen Jones believed might work (29 April).

If Russell Brand became a late convert to Ed Miliband's cause, other celebrities proved far more willing. High profile endorsements by famous supporters have sometimes been dismissed as an irrelevance but the Star, the least political of newspapers, might not have reported on a Labour rally but for the presence of comedian Eddie Izzard, chef Delia Smith and a range of other familiar faces (5 May). Famous Conservatives like Andrew Lloyd-Webber also made electoral interventions, warning Mail on Sunday readers '(D)on't sleepwalk to disaster' in an article accompanied with a mock-up of Sturgeon and Miliband as characters from the composer's Phantom of the Opera musical (26 April). Reality television celebrity Amy Childs from ITV2 programme The Only Way Is Essex made a front-page denunciation of 'scroungers' before later reappearing in the Sun with blue rosette to endorse Cameron (6 April). Actor Tom Conti, a self-confessed 'life-long Labour luvvie', confirmed he had switched allegiance to the Tories in an article for the Daily Mail (6 May). Performers also featured in Labour Party Election Broadcasts, the first of which was introduced by Martin Freeman. Actor Freeman was subsequently dismissed as 'Red Ed's celebrity phony' by the Mail for having schooled his children privately and not paid his partner's outstanding tax bill despite reportedly being a multi-millionaire (1 April) 


\section{Follow the money: economy and tax affairs}

The economy was the major substantive policy issue in terms of newspaper reporting of the election (Table 3). Much of this coverage was filtered through the prism of the title's editorial standpoint and here a reinvigorated 'Tory press' really came in to its own. ${ }^{\text {xvi }}$ The most prominent example of an agenda-setting story was the Daily Telegraph's publication of the letter signed by corporate executives: '100 business chiefs: Labour threatens Britain's recovery' (1 April). A feature in the following day's Times reinforced this message: 'Labour has alarmed businesses with its attitude to lower taxes and a flexible labour market. These are vital to a strong economy' (2 April). The Sun promoted similar concerns in a feature '120 EXECS COME OUT BACKING TORIES' focusing on criticisms of Miliband's proposed ban on zero hour contracts (2 April). Employment had previously featured in 'WE'RE JUST THE JOB', which pointedly applauded the $1.9 \mathrm{~m}$ 'jobs created in the last 5 years under (the) Tories' rather than the Coalition (Sun 31 March). The Sun also published their own list of 100 small business people supporting the Conservatives including some former Labour voters who were quoted in the piece ('SHOP KEEPERS OF THE WORLD UNITE', 13 April). Two weeks later Baroness Karren Brady exceeded this effort by a considerable margin when she revealed the names of 5000 self-employed workers who were going to vote Tory (Daily Telegraph, 27 April).

In a guest Sunday Telegraph column, David Cameron set out his key campaign theme: 'We've saved the economy from ruin- don't let Miliband spoil it' (26 April). Cameron's view was echoed by a range of sympathetic commentators most notably in The Times which ran an editorial, 'Clear Cut', claiming the government's austerity was both successful and a necessity (1 April). The newspaper also made several pointed references to the Labour leader ('Miliband would send Britain $£ 90 \mathrm{Bn}$ further into the red', 24 April; 'Miliband is bad for business, warn FTSE executives', and 'Miliband savaged for "lies" over spending', both 1 May) and his allegedly flawed budgetary plans ('Labour manifesto leaves voters clueless on cuts, experts claim', 14 April). Other print media commentators were more circumspect in their economic analysis. The Observer challenged the rival campaigners to be more candid and provide fuller details as to their budgetary plans ('Politicians, be honest about Britain's finances', editorial, 26 April). Writing in the Financial Times, the influential 
journalist Martin Wolf questioned prevailing orthodoxy when he argued '(E)conomics is the loser in this political contest'. Wolf further suggested neither of the main parties were 'competent' and that they both lacked a 'healthy scepticism' towards the financial services industry and over the state of the housing market, two factors he believed had helped to cause the 2008 crisis (6 May).

Closely linked to economics, taxation also featured prominently in newspaper reporting of the campaign. Following George Osborne's announcement he was raising the inheritance threshold, the Daily Express welcomed the move against what it called the 'hated death tax' (13 ${ }^{\text {th }}$ April). The Mail on Sunday was similarly effusive, applauding the measure having interviewed the Chancellor ('Cheers! George, E1million tax gift', 12 April). Osborne, a possible successor to Cameron, featured prominently in 'ST GEORGE'S PAY', a Sun story with a mock-up of him as the nation's patron saint and the declaration that ' $(\mathrm{H}) \mathrm{e}$ vows lowers tax for English workers' $\left(24^{\text {th }}\right.$ April). In sharp contrast the paper had earlier warned of the ' $€ 3,028$ COST OF VOTING ED' from additional taxes that would be levied on households in the event of a Miliband victory (28 March).

The Mirror articulated the Labour case on tax and associated credits, claiming ' $4.3 \mathrm{M}$ families could lose out on $£ 1,000$-a-year child benefit' under proposals drawn up by the Conservatives (8 April). Similarly its Sunday sister reported: 'OSBORNE PLOTS TOP RATE TAX CUT AS REST OF US STRUGGLE' (Sunday Mirror, 5 April). The Mirror titles also gave prominence to another supposed instance of Tory favouritism towards the rich when it criticised the party's failure to act over the status of so-called 'non-dom' citizens while simultaneously welcoming Labour's plans to '(H)ome in on tax avoiders' ('NON-DOMS DOOMSDAY', Daily Mirror 8 April). The paper further alleged the Prime Minister's late father had been a high profile beneficiary of allegedly dubious financial arrangements ('Cam's dad dodged tax', 1 May). Although the Times dismissed Labour's 'non-dom' policy as counterproductive 'Tax Twaddle' (9 April), Jonathan Guthrie of the $F T$ pointedly disagreed, questioning whether it was credible to defend the status quo (Financial Times, 8 April). But ultimately Miliband and his strategists must have felt impotent in trying to rebut the Conservatives' single-minded economic argument while simultaneously trying to articulate their own courtesy of a largely hostile print media. 


\section{Opposition matters? The constitution and other issues}

The Coalition's promotion of austerity measures guaranteed the economy and taxation would feature prominently in the campaign. Similarly the 2014 Scottish Independence Referendum transformed the electoral landscape, and not just north of the border, guaranteeing the future of the Union would also be a major campaign issue (see Table 3). The SNP's subsequent rise in the polls led to widespread speculation that it would play a decisive role in a hung parliament. Following Nicola Sturgeon's confirmation that she would never support the Conservatives in such a scenario, several newspapers speculated on what The Financial Times called the 'wish list' the First Minister was likely to present Miliband as the price of power (21 April). Others viewed this as a threat. A Times' editorial presented 'The SNP Challenge' as a 'dangerous trap' for Labour (17 April) before returning to the subject in a front-page story days later ('We will hold UK defence to ransom, SNP warns', The Times 20 April). For Janet Daley the prospect of a pact between the Nationalists and Labour 'would be an outrage to democracy' (Sunday Telegraph 26 April). Daley's colleagues on the daily sister paper believed it would precipitate a 'Nightmare in Downing Street' (Daily Telegraph 6 May). Underlying such a view was the contention, articulated by Robert Hardiman among others, that SNP politicians were 'bungling, neurotic far-Left dinosaurs who'll wreck their booming economy' (Daily Mail 18 April).

The press rhetoric attacking the Nationalists became highly personalised and aimed on Nicola Sturgeon following her well-received performance in the seven-way leader debate. In a hyperbolic front-page Daily Mail story on the 'Queens of Scots' Sturgeon was, as has been previously noted, labelled the 'MOST DANGEROUS WOMAN IN BRITAIN' (4 April). A similar Sunday Express story even suggested there was a 'cult' around the First Minister (5 April). In sharp contrast to her sympathetic portrayal in its Scottish edition, the English Sun profiled Sturgeon as 'The Scotweiler', a reference to her supposed ruthlessness that extended back to childhood when the paper claimed she had cut the hair off her sister's doll. The same feature also likened the SNP leader to the diminutive 1980s comedy character 
Jimmy Krankie (The Sun 25 April). More cerebral commentators like Jonathan Freedland questioned whether this kind of coverage might further alienate the Scots and hasten the end of the Union (Guardian, 25 April). Freedland's Guardian followed this up with a piece by Democratic Unionist leader Nigel Dodds who warned that political expediency, in the guise of the fierce rhetoric being directed at the SNP, threatened to undermine the integrity of the United Kingdom (Guardian, 27 April).

Integrity of a different kind had been a major theme in coverage of the last General Election following the MPs' expenses scandal. This time around politicians' standards of conduct was an issue but press reports on the subject included a more varied range of alleged misdemeanours. Certain UKIP activists were, for instance, identified as having been involved in far right groups such as the English Defence League and National Front ('Manifestoads', Daily Mirror 16 April; Mail on Sunday 3 May). But most of this kind of coverage focused on the perceived flaws of leading politicians. Prior to the campaign Daily Mail columnist Sarah Vine had criticised the 'bland, functional, humourless, cold' character of a utility room she had wrongly believed- following a television profile- to be the Labour leader's family kitchen. xvii Although this assumption was soon corrected The Sun revisited the controversy by accusing Miliband of being an elitist hypocrite. In a front-page piece the paper depicted the politician as an aristocratic character from popular period drama Downton Abbey: 'We DO have two kitchens... nanny uses the one downstairs' (Sun, 16 April). Toby Young, guest columnist on the paper's Sunday sister, had earlier suggested 'Ed has two faces' in a wide-ranging critique that also attacked the 'hypocrisy' of the prospective Prime Minister and questioned his fitness to govern (Sun on Sunday, 12 April). Young also criticised Miliband for having, in his view, betrayed sibling David to win the party leadership. 'Bozfather' Boris Johnson reiterated the point in an interview with the paper: 'Ed stabbed his own brother in the back... family don't do that' (Sun on Sunday, 26 April). The interview with Johnson was illustrated with a photograph from classic film The Godfather of the eponymous character and the errant brother he murdered.

The charge of hypocrisy was levelled at Labour politicians other than Miliband. Shadow Chancellor Ed Balls' alleged failure to pay a window installer was highlighted by the Mail on Sunday in an attempt to question his financial probity ('Exposed: Balls the cheque bouncer', 3 May). Another prospective minister Toby 
Perkins' payment of $£ 4$ an hour, a level well below the minimum wage, to campaign interns led to a front-page Sun denunciation of 'SLAVE LABOUR' (21 April). Conservative candidates also found themselves accused of impropriety with Sir Paul Beresford challenged by the Mirror over why he was reportedly '(F)illing his boots' through spending the campaign working at his dental practice rather than meeting constituents (2 May). More embarrassing were the same paper's front-page allegations of online misconduct levelled against Tory Co-Chairman Grant Shapps ('Thicky Wiki', 22 April). The charge that Shapps had doctored Wikipedia entries for senior party colleagues was challenged by a Telegraph report that claimed his accuser was a politically motivated 'Lib Dem activist' (Daily Telegraph 23 April). The Tory (press) ability to refute accusations of impropriety had been earlier demonstrated by the swift rebuttal, via the Times, of a potentially damaging claim by Danny Alexander (which had made the Independent front-page) that a then Conservative colleague had told him 'we're for the bosses, you're for the workers' when both were members of the Cabinet (Independent 6 April; 'Alexander accused of lying over Tory claim to be "taking care of bosses"', The Times 7 April).

Labour focused on the NHS as a key if not the major theme of its campaign. Perhaps partly because of this the issue did not rank higher up the print media agenda (Table 3). Interestingly George Osborne chose the Guardian to write a report on his intention to provide an extra £8bn health funding a year (11 April). But more often it was Labour inclined newspapers that tried to move the debate onto the future of the NHS. Emulating an approach deployed by rival titles, the Guardian published a letter to the paper from 100 eminent clinicians in an attempt to highlight concerns over the future of the health service ('Senior doctors assess the government's record on the NHS', 8 April). The Daily Mirror also ran a series of stories alleging the Conservatives had broken promises on GP recruitment ('DR NO', 7 April) and a warning from Labour supporting celebrity chef Delia Smith that the health service could not go on being 'treated like a supermarket' (4 May). The last Sunday Mirror before polling day featured Ed Miliband warning of a 'Tory plague' and alerting readers to the 1000 reasons not to trust the Conservatives on health. Miliband advised readers that there were '100 HOURS TO SAVE THE NHS' by voting Labour (3 May). 
If health was the key issue for Labour, immigration had long been a prominent theme for UKIP campaigners. And although it did not formally endorse Nigel Farage, the Star ran several prominent stories on the topic despite consciously devoting less attention to the election than any of its rivals. The paper approvingly reported comments by a Polish born party candidate that 'Immigration is great- but Britain is too overcrowded' ('UKIP DEAD RIGHT ON SAYS POLE', 4 May). Farage was also quoted attacking Labour for 'betraying working-class voters' through siding with 'multinational corporations which benefit from mass immigration while damaging small firms and local communities' (20 April). The Star itself took to criticising the Conservatives with a blunt message: 'GET TOUGHER ON MIGRANTS, DAVE' (24 April). The same feature cited an Ipsos MORI poll to argue '(V)oters want the Tories to be far tougher on mass immigration'. Perhaps anticipating this kind of critique David Cameron offered a personal response in a rival newspaper the same day ('Why you can only trust the Tories on migration', Daily Mail, 24 April). But overall the issue did not register on the election agenda as it had in previous campaigns. Significantly this was despite an ongoing crisis in the Mediterranean involving displaced people fleeing Libya and incendiary comments by Sun columnist Katie Hopkins that likened them to 'cockroaches' ('Rescue boats? I'd use gunships to stop migrants', The Sun 17 April).

\section{The readers have their say: voting by newspaper}

Citizens tend to buy newspapers that conform with, and confirm, their own views. The most obvious examples are the high proportions of Labour and Conservative voters reading the Mirror and the Daily Telegraph respectively. Table 4 provides Ipsos MORI data on the voting patterns of these and other titles' readers in the 2015 General Election with the corresponding figures for 2010. It is noteworthy that, for the most part, levels of support for the major two parties are broadly consistent for each newspaper across the two elections. By contrast there were dramatic falls in backing for the Liberal Democrats among readers of both the popular and quality titles reflecting the decline in the party's fortunes since the media-related 'Cleggmania' phenomenon of 2010. ${ }^{\text {xviii }}$ Conversely it is quite striking how support for UKIP has grown among newspapers readers. Those buying popular titles were 
noticeably more likely to vote for Farage's party than the public as a whole. This may reflect the ageing profile and other demographic factors associated with the audiences in question. It should not, however, be assumed that these former Liberal Democrat supporting readers have defected to UKIP as suggested by the broad trend indicated by the voting figures. Rather there is likely to have been a considerable amount of churn in these figures with varied patterns in switches of support for parties between these newspaper consumers. The decline in circulations is also another factor to be considered here.

The voting figures for readership confirm a longer-term trend, specifically that there have always been significant minorities who have not supported their newspaper's electoral choice. Turning to particular examples, more than a quarter of Sun readers voted Labour as they had in 2010. But 2015 saw marked growth in support and publicity for other parties and this fragmentation partly explains some of the striking disparities between voter affiliations and the editorial stances of their favoured newspapers. Here there was, as has been noted, a considerable rise in backing for UKIP. For example, around one fifth of Sun and Mirror readers voted for the party in this election and thereby disregarded the very strong preference of their own newspapers that are, respectively, known for being antagonistic and sympathetic towards the European Union. Similarly the endorsement by the Express, the one title that formally backed UKIP, still resulted in the Conservatives securing a greater level of support among that paper's readers than Nigel Farage's party. Evidence of independent thinking on the part of readers is not surprising: people buy newspapers for many reasons and their decision as to how to vote is the product of a complex set of interacting factors. Media influence is only ever likely to be a contributory element, particularly in an era where mass audiences are increasingly in decline. Whether or not newspapers were, or ever could be, electorally influential is a question that is part of a long-running debate. ${ }^{\text {xix }}$ But in 2015 there was plenty of evidence, in the guise of the traditional, highly partisan press campaigns, to suggest both politicians and editors still believed in the opinion-forming power of the medium. 


\section{Conclusion}

The campaign witnessed the return to the kind of robust press partisanship not seen since 1992 when The Sun (in)famously published a highly negative front-page denunciation of the then Labour leader. The paper repeated this with another eveof-poll attempt to demolish the credibility of the opposition. And it was this and other similarly polemical editorialising that led former Sunday Times turned BBC broadcaster Andrew Neil to describe it as the 'British press at (its) partisan worst' and lament the end of 'all pretence of separate between news and opinion gone'. ${ }^{x x}$ This was evident in so-called 'quality' as well as 'popular' titles with the Telegraph and Guardian joining the Sun and Mirror in their attempts to frame events in ways conducive to their clearly favoured party's interpretations. Much newspaper reporting of the campaign was therefore coloured by editorial judgement. Readers solely reliant on their newspaper for coverage would have received a highly partial, selective account of the election. And although press circulations were down by a third from 2010, the sales of printed copies still ensured this most traditional news medium reached millions of voters. These readers will have included many who buy their paper for various reasons rather than politics but who will nonetheless have been exposed to some of the strident partisanship.

It was intriguing that UKIP, the party that saw the most significant rise in its support during the election, did even better among the newspaper buying public at large despite having comparatively little formal press support. This trend reflects underlying demographic factors, notably the older age profile of readerships. It also raises the possibility that if there was any press effect (and this has been notoriously difficult to detect during the past and in an era of greater newspaper consumption), the most plausible interpretation of the anti-Labour coverage's impact appears to have been to marginally improve the Conservatives' position while more significantly boosting the UKIP campaign. This reflects on the way press partisanship and ideology are connected but still distinctive elements of a given newspaper's identity. Despite 'voting' for Labour during the Blair era, titles like the Sun and News of the World retained their core political beliefs. These values were evident in this campaign and clearly informed a now reinvigorated 'Tory press' approach. Stories 
on the economy, Europe and immigration during this election were hostile to Labour and the party's would be SNP allies but in ways that were conducive to the UKIP as well as the Conservative cause. So, having acknowledged the rise of multi-party politics in advance of another hung parliament scenario, the bulk of the partisan print media still returned to their preoccupation with the left-right binary divide to offer a traditionally partisan perspective on the merits of otherwise of a Cameron or Miliband-led government. 
Table 1: Daily newspapers' partisanship and circulation ${ }^{\mathrm{xxi}}$

\begin{tabular}{|c|c|c|c|c|}
\hline $\begin{array}{l}\text { Title } \\
\text { Proprietor } \\
\text { (Chair) } \\
\text { Editor }\end{array}$ & $\begin{array}{l}\text { Declaration } \\
\text { (2010) }\end{array}$ & $\begin{array}{l}\text { Circulation }^{\mathrm{a}} \\
(2010) \\
(000 \mathrm{~s})\end{array}$ & $\begin{array}{l}\text { Print } \\
\text { readership } \\
\text { (000s) }\end{array}$ & $\begin{array}{l}\text { Print and } \\
\text { online }^{c}\end{array}$ \\
\hline $\begin{array}{l}\text { Daily Mirror } \\
\text { Trinity Mirror } \\
\text { (David Grigson) } \\
\text { Lloyd Embley } \\
\end{array}$ & $\begin{array}{l}\text { Very Strong Labour } \\
\text { (Strong } \quad \text { Labour) }\end{array}$ & $\begin{array}{l}882 \\
(1240)\end{array}$ & $\begin{array}{l}2,211 \\
(3,425)\end{array}$ & 2,726 \\
\hline $\begin{array}{l}\text { Daily Express } \\
\text { Northern and Shell } \\
\text { (Richard Desmond) } \\
\text { Hugh Whittow }\end{array}$ & $\begin{array}{ll}\text { Very Strong UKIP } & \\
\text { (Very } & \text { Strong } \\
\text { Conservative) } & \end{array}$ & $\begin{array}{l}438 \\
(666)\end{array}$ & $\begin{array}{l}993 \\
(1,577)\end{array}$ & 1,145 \\
\hline $\begin{array}{l}\text { Daily Star } \\
\text { Northern and Shell } \\
\text { (Richard Desmond) } \\
\text { Dawn Neesom }\end{array}$ & $\begin{array}{l}\text { No declaration } \\
\text { (No declaration) }\end{array}$ & $\begin{array}{l}420 \\
(823)\end{array}$ & $\begin{array}{l}943 \\
(1,965)\end{array}$ & 1,065 \\
\hline $\begin{array}{l}\text { The Sun } \\
\text { News UK } \\
\text { (Rupert Murdoch) } \\
\text { David Dinsmore }\end{array}$ & $\begin{array}{l}\text { Very Strong Conservative } \\
\text { (Strong Conservative) }\end{array}$ & $\begin{array}{l}1858 \\
(2956)\end{array}$ & $\begin{array}{l}5,178 \\
(7,761)\end{array}$ & 5,237 \\
\hline $\begin{array}{l}\text { Daily Mail } \\
\text { Associated } \\
\text { Newspapers } \\
\text { (Lord Rothermere) } \\
\text { Paul Dacre }\end{array}$ & $\begin{array}{l}\text { Very Strong Conservative } \\
\text { (Strong Conservative) }\end{array}$ & $\begin{array}{l}1631 \\
(2096)\end{array}$ & $\begin{array}{l}3,704 \\
(4,934)\end{array}$ & 5,463 \\
\hline $\begin{array}{l}\text { Daily Telegraph } \\
\text { Telegraph Group } \\
\text { (Barclay Brothers) } \\
\text { lan MacGregor } \\
\end{array}$ & $\begin{array}{l}\text { Very Strong Conservative } \\
\text { (Moderate Conservative) }\end{array}$ & $\begin{array}{l}486 \\
(683)\end{array}$ & $\begin{array}{l}1,119 \\
(1,905)\end{array}$ & 2,138 \\
\hline $\begin{array}{l}\text { The Guardian } \\
\text { Scott Trust } \\
\text { (Liz Forgan) } \\
\text { Alan Rusbridger }\end{array}$ & $\begin{array}{ll}\text { Moderate } & \text { Labour } \\
\text { (Moderate } & \text { Liberal } \\
\text { Democrat) } & \end{array}$ & $\begin{array}{l}176 \\
(289)\end{array}$ & $\begin{array}{l}761 \\
(1,147)\end{array}$ & 2,130 \\
\hline $\begin{array}{l}\text { The Times } \\
\text { News UK } \\
\text { (Rupert Murdoch) } \\
\text { John Witherow } \\
\end{array}$ & $\begin{array}{lr}\text { Moderate } & \text { Conservative- } \\
\text { Liberal } & \text { Democrat } \\
\text { Coalition } & \\
\text { (Weak Conservative) }\end{array}$ & $\begin{array}{l}394 \\
(507)\end{array}$ & $\begin{array}{l}788 \\
(1,773)\end{array}$ & 1,367 \\
\hline $\begin{array}{l}\text { The Independent/i } \\
\text { Independent Print } \\
\text { Limited } \\
\text { (Evgeny Lebedev) } \\
\text { Amol Rajan } \\
\text { (The independent) } \\
\text { IOliver Duff (i) }\end{array}$ & $\begin{array}{l}\text { Weak } \quad \text { Liberal } \\
\text { Democrat- } \\
\text { Conservative Coalition } \\
\text { (Moderate Lib Dem) }\end{array}$ & $\begin{array}{l}\text { Independent } \\
59 \\
(188) \\
\\
i \\
276 \\
\end{array}$ & $\begin{array}{l}995 \\
(671)\end{array}$ & 1,026 \\
\hline $\begin{array}{l}\text { Financial Times } \\
\text { Pearson plc } \\
\text { (Glen Moreno) }\end{array}$ & $\begin{array}{ll}\text { Conservative- } & \text { Liberal } \\
\text { Democrat Coalition } & \\
\text { (Very } & \text { Weak } \\
\text { Conservative) } & \end{array}$ & $\begin{array}{l}212 \\
(387)\end{array}$ & Not available & $\begin{array}{l}\text { Not } \\
\text { available }\end{array}$ \\
\hline
\end{tabular}


Table 2: Sunday newspapers' partisanship and circulation

\begin{tabular}{|c|c|c|c|}
\hline Title & Declaration & Circulation $^{\mathrm{a}}$ & Readership $^{b}$ \\
\hline Sunday Mirror & $\begin{array}{l}\text { Very Strong Labour } \\
\text { (Strong Labour) }\end{array}$ & $\begin{array}{l}833 \\
(1,124)\end{array}$ & $2,401(3,826)$ \\
\hline Sunday Express & $\begin{array}{l}\text { Very Strong UKIP } \\
\text { (Very Strong Conservative) }\end{array}$ & $\begin{array}{l}385 \\
(574)\end{array}$ & $1,150(1,622)$ \\
\hline $\begin{array}{l}\text { Sun on Sunday } \\
\text { (News of the World) }\end{array}$ & $\begin{array}{l}\text { Strong Conservative } \\
\text { (Very Strong Conservative) }\end{array}$ & $\begin{array}{l}1,474 \\
(2,906)\end{array}$ & $4,207(7,602)$ \\
\hline People & $\begin{array}{l}\text { Moderate Labour } \\
\text { (None) }\end{array}$ & $\begin{array}{l}324 \\
(530)\end{array}$ & $\begin{array}{l}674 \\
(1,331)\end{array}$ \\
\hline Mail on Sunday & $\begin{array}{l}\text { Strong Conservative } \\
\text { (Strong Conservative) }\end{array}$ & $\begin{array}{l}1,447 \\
(1,983)\end{array}$ & $4,007(5,213)$ \\
\hline Star on Sunday & $\begin{array}{l}\text { No declaration } \\
\text { (No declaration) }\end{array}$ & $\begin{array}{l}254 \\
(348)\end{array}$ & $\begin{array}{l}254 \\
(348)\end{array}$ \\
\hline Sunday Telegraph & $\begin{array}{l}\text { Strong Conservative } \\
\text { (Strong Conservative) }\end{array}$ & $\begin{array}{l}371 \\
(510)\end{array}$ & $1,150(1,677)$ \\
\hline Observer & $\begin{array}{l}\text { Moderate Labour } \\
\text { (Moderate Liberal Democrat) }\end{array}$ & $\begin{array}{l}196 \\
(332)\end{array}$ & $\begin{array}{l}723 \\
(1,212)\end{array}$ \\
\hline Sunday Times & $\begin{array}{l}\text { Moderate Conservative } \\
\text { (Strong Conservative) }\end{array}$ & $\begin{array}{l}809 \\
(1,135)\end{array}$ & $2,010(3,219)$ \\
\hline $\begin{array}{l}\text { Independent } \\
\text { Sunday }\end{array}$ & $\begin{array}{l}\text { No declaration } \\
\text { (No declaration) }\end{array}$ & $\begin{array}{l}99 \\
(168)\end{array}$ & $\begin{array}{l}363 \\
(600)\end{array}$ \\
\hline
\end{tabular}

${ }^{a}$ Audit Bureau of Circulation (April 2015)

${ }^{\mathrm{b}}$ National Readership Survey (April 2014-March 2015) 
Table 3: Campaign issues- top 10 in the press

\begin{tabular}{|l|l|l|}
\hline Rank & Press & $\%$ \\
\hline 1 & Election process & 44.5 \\
\hline 2 & Economy & 10.5 \\
\hline 3 & Taxation & 6.5 \\
\hline 4 & Standards & 3.8 \\
\hline 5 & Constitutional & 3.7 \\
\hline 6 & NHS & 3.7 \\
\hline 7 & Immigration/Race & 3.5 \\
\hline 8 & Europe & 3.4 \\
\hline 9 & Employment & 2.9 \\
\hline 10 & Business & 2.6 \\
\hline
\end{tabular}

Source: Loughborough Communication Research Centre ${ }^{x x i i}$

Table 4: Voting by newspaper readership (equivalent figures for 2010 in brackets)

\begin{tabular}{|l|l|l|l|l|l|l|l|}
\hline Party/Vote \% & $\begin{array}{l}\text { Cons } \\
\mathbf{3 7}(\mathbf{3 6})\end{array}$ & $\begin{array}{l}\text { Labour } \\
\mathbf{3 0}(\mathbf{2 9})\end{array}$ & $\begin{array}{c}\text { Lib Dem } \\
\mathbf{8}(\mathbf{2 3})\end{array}$ & $\begin{array}{l}\text { UKIP } \\
\mathbf{1 3}(\mathbf{3})\end{array}$ & $\begin{array}{l}\text { SNP } \\
\mathbf{5}(\mathbf{2})\end{array}$ & $\begin{array}{l}\text { Green } \\
\mathbf{4}(\mathbf{1})\end{array}$ & $\begin{array}{l}\text { Other } \\
\mathbf{3}(\mathbf{6})\end{array}$ \\
\hline Mirror & $14(16)$ & $62(59)$ & $2(17)$ & $19(-)$ & $1(-)$ & $1(-)$ & $1(8)$ \\
\hline Express & $44(53)$ & $16(19)$ & $4(18)$ & $33(-)$ & $1(-)$ & $1(-)$ & $1(10)$ \\
\hline Sun & $39(43)$ & $27(28)$ & $3(18)$ & $23(-)$ & $6(-)$ & $1(-)$ & $2(10)$ \\
\hline Mail & $57(59)$ & $16(16)$ & $6(16)$ & $18(-)$ & $2(-)$ & $1(-)$ & $1(10)$ \\
\hline Telegraph & $72(70)$ & $8(7)$ & $5(18)$ & $11(-)$ & $1(-)$ & $1(-)$ & $1(5)$ \\
\hline Guardian & $16(9)$ & $50(46)$ & $13(37)$ & $2(-)$ & $7(-)$ & $10(-)$ & $2(8)$ \\
\hline The Times & $60(49)$ & $17(22)$ & $11(24)$ & $6(-)$ & $3(-)$ & $2(-)$ & $3(5)$ \\
\hline Independent & $17(14)$ & $47(32)$ & $16(44)$ & $4(-)$ & $3(-)$ & $11(-)$ & $1(10)$ \\
\hline
\end{tabular}

Source: Ipsos MORI ${ }^{\mathrm{XXI}}$

\footnotetext{
' Alastair Campbell, 'Newspaper election coverage is beyond parody', theguardian.co.uk, 7 May 2015. Unless otherwise stated all newspaper references in the chapter are to printed, hard copy versions of the item.

ii Steven Barnett (2015) 'Four reasons why a partisan press helped win it for the Tories'. In: Dan Jackson and Einar Thorsen (eds) UK Election Analysis 2015: Media, Voters and the Campaign. Bournemouth University Centre of the Study of Journalism, Culture and Community. See also Dominic Wring and Stephen Ward, 2015, 'Exit Velocity: the Media Campaign', in Andrew Geddes and Jonathan Tonge (eds.) Britain Votes 2015. Oxford: Oxford University Press.
} 
iii Marie Thibault (2006, ed.) Why newspapers matter, MIT Communications Forum, October (http://web.mit.edu/comm-forum/forums/newspapers matter.html).

iv Adam Sherwin and Oliver Wright, "Murdoch berated "Sun" journalists for not doing enough to attack Miliband', The Independent, 21 April 2015.

${ }^{v}$ Nick Davies, 2014, Hack Attack, London: Faber \& Faber.

vi Sherwin and Wright, ibid.

vii Jessica Elgot, 'The Sun criticised over offer to pay $£ 100$ to Tory voters for "good news" stories', theguardian.com, 6 May 2015.

viii Colin Seymour-Ure, 1974, The Political Impact of the Media. London: Constable.

${ }^{\text {ix }}$ Rajeev Syal, 'Three business leaders distance themselves from pro-Tory letter', theguardian.com, 2 April.

× Joe Murphy, 'Ed Miliband battles with a bacon sandwich as he buys flowers for his wife at London market', Evening Standard, 21 May 2014.

${ }^{x i}$ Keith Kahn-Harris, 'Is the Sun's "Save Our Bacon" front page anti-Semitic?', theguardian.com/commentisfree, 6 May, 2015.

xii The Daily Mail had previously courted controversy in autumn 2013 when it published an article by Geoffrey Levy claiming Ed Miliband's academic father was 'The Man Who Hated Britain' on account of his Marxist views. The newspaper found itself having to defend its stance: 'Daily Mail's position on Miliband unravelling- Labour', BBC News 4 October 2013 (http://www.bbc.co.uk/news/uk-politics24395790).

xili Leo McKinstry, 'A Miliband victory would be a total disaster for the UK', Daily Express, 4 May 2015; Stephen Pollard, 'Miliband would take Britain back to the 1970s', Daily Express, 22 April 2015.

xiv Dominic Wring and David Deacon, 2010, 'Patterns of Press Partisanship in the 2010 General Election', British Politics, 5, pp.436-454.

${ }^{x v}$ Jon Stone, 'The Daily Telegraph's editor just emailed its subscribers telling them to vote Tory', ww.independent.co.uk, 7 May 2015.

xvi Ivor Gaber, 'The "Tory Press" rides again', in Jackson and Thorsen, ibid.

xvii Sarah Vine, 'Why their kitchen tells you all you need to know about the mirthless Milibands... and why there's nothing to suggest that Ed and Justine are not, in fact, aliens', dailymail.co.uk, 12 March 2015.

xviii Margaret Scammell and Charlie Beckett, 'Labour No More: The Press', in Dennis Kavanagh and Philip Cowley, 2010, The British General Election of 2010. Hampshire: Palgrave Macmillan.

${ }^{x i x}$ See Barnett, ibid., and also Roy Greenslade, "Yes, Rightwing Newspaper Coverage Did Cause Ed Miliband's Downfall', theguardian.com, 11th May 2015.

xx Jack Sommers, 'General Election Front Pages Show The British Press At its "Partisan Worst", BBC's Andrew Neil Says', The Huffingon Post UK, $6^{\text {th }}$ May 2015

xxi The equivalent figures for 2010 in brackets are courtesy of Wring and Deacon, ibid. When considering press partisanship it is important to account for the choice of party a given newspaper chooses to support but also the strength of that endorsement. The key piece of information to determine this is the editorial declaration. Traditionally this used to be published on polling day itself but now increasingly appears in the days and even the week before. Although the statement is, by definition, limited in terms of both time and space it is nonetheless of significance. The editorial declaration conveys a viewpoint that normally reflects the newspaper's political outlook as expressed in the preceding campaign. It is also something that the key decision-making editors, proprietors and/or journalists traditionally take very seriously.

Close analysis of editorials provides the most accessible way of comparing newspapers with the strength (or not) of both their rivals' as well as their own previous allegiances. Thus when sections of the so-called 'Tory press' of the 1980s morphed into the 'Tony press' the following decade it became important to understand this shift of partisan allegiance did not necessarily mean a changes in the more fundamental ideological outlook of a given title. Consequently it was important to analyse and 
qualify this apparent shift in support from one party to another. The Sun endorsement of Tony Blair was, for instance, more a personal vote of confidence in him than his party and was characteristically 'weak' compared to the 'strong' support given to the Margaret Thatcher led Conservatives.

Where a newspaper endorsement has been deemed 'very strong' it reflects the one-sided nature of the editorial that can often be more negative about the opposition than positive about the preferred party. The description 'strong' applies to a statement that contains some qualification about the paper's chosen politicians. This, however, is still a clearer signal of intent compared to the 'moderate' endorsement, a stance that delivers an identifiable judgement but with caveats. 'Weak' statements are characteristically tentative and highly qualified. 'Very weak' endorsements state a preference but do so in the mildest of ways. Partisanship has in the past been attributed to newspapers without these evaluations and this only provides limited insight into the nature rather than intensity of that media support for one or other party. For more on this see David Deacon and Dominic Wring, 'Partisan Dealignment and the British Press ', in John Bartle, Ivor Crewe and Brian Gosschalk, 2002 eds., Political Communications: the British General Election of 2001. London: Frank Cass, pp.197211.

xxii David Deacon, John Downey, James Stanyer and Dominic Wring (2015) 'News Media Performance in the 2015 General Election Campaign', in Jackson and Thorsen, ibid. xxiii Thanks to Roger Mortimore of Ipsos MORI for the figures in Table 4. 